\title{
ZA JANEM SOKOLEM
}

V úterý 16. února odešel ve věku nedožitých osmdesáti pěti let profesor Jan Sokol, filosof, vysokoškolský učitel, překladatel, disident a politik.

Je těžké vyjmenovat, kým vším Jan Sokol byl - ten výčet by byl dlouhý, i kdyby se měl omezit jen na seznam povolání, která v různých etapách svého života zastával. Zdá se až neuvěritelné, že někdo dokáže uspět v tolika tak různých profesích. Jan Sokol začal řemeslem - vyučil se zlatníkem a pracoval jako jemný mechanik. Jakkoli byl k řemeslu donucen režimem, který mu nedovolil studovat, vzpomínal na ně rád. A ačkoli je pak opustil, smysl pro poctivost ve všem, co dělal, a přesnost a preciznost, kterou zlatník musí mít, mu zůstaly: i když pracoval se slovem - i tehdy byl přesný a precizní.

$\mathrm{Na}$ vysokou školu se nakonec přece jen dostal: nejprve sice jen do dílny Fakulty technické a jaderné fyziky Univerzity Karlovy, kde se podílel na stavbě lineárního urychlovače, později jako dálkový student Fakulty matematicko-fyzikální. To už ale pracoval ve Výzkumném ústavu matematických strojů, kde vedl vývoj programových systémů. Ačkoli sám obor nevystudoval, byl v něm dobrý, ba vynikající, a to ve své době nejen v rámci naší republiky. Proto mohl vést a učit ostatní kolegy. A mimo jiné i proto ho nevyhodili z práce po podpisu Charty 77: jako programátora ho potřebovali. (Ovšem samozřejmě nejen jeho, VÚMS byl útočištěm pro více tehdejšímu režimu názorově nepohodlných lidí.)

První publikace Jana Sokola nebyly filosofické, ale týkaly se právě programování a operačních systémů. Vedle těch úzce odborných napsal i popularizační knížku Jak počítá počítač, která vyšla také v němčině a mad’arštině. Nejen ve filosofii, ale též v otázkách technických se snažil o srozumitelnost i pro široký okruh nezasvěcených. Možná v tom byl první náznak učitele, kterým se později stal. Sám rád přicházel věcem na kloub a uměl vysvětlit, jak fungují. Snad v tom byla jeho vrozená zvídavost, možná to bylo i díky jeho dědečku Nušlovi, matematiku a astronomovi, který jej hodně ovlivnil a na kterého často a rád vzpomínal. Ten ho také na ondřejovské hvězdárně zasvěcoval do tajů různých astronomických a geodetických př́strojů, z nichž některé dokonce sám vymyslel. Jan Sokol byl schopný vysvětlit princip fungování ledasčeho, vnímal a reflektoval ale také změnu, resp. předěl, který během jeho života nastal - totiž že už ani při nejlepší vůli není běžný člověk schopen pochopit princip strojủ a př́istrojů, které užívá a s nimiž zachází. Ostatně nejen uživatel, ale ani ten, který konstruuje určitou část technických zařízení, není schopen porozumět tomu, jak funguje celek. Jan Sokol ovšem dokázal vysvětlit mnohé.

Přiznávám, že mi to imponovalo - a nejen pokud šlo o techniku moderní. Daleko spíše jsem obdivovala, jak se vyzná v již dávno nepoužívaných postupech starých zeměměřičů a astronomů, kteří se dobrali tak neuvěřitelně přesných údajů. V postupech, které byly znamením vstupu do světa geometrického, v němž byl doma i Jan Sokol. Možná opět díky dědečku Nušlovi, a ostatně i dědeček Sokol byl matematik. 
Jan Sokol měl matematiku rád a hlavně věděl, jak je v životě důležitá. I proto byl přesvědčeným zastáncem povinné maturitní zkoušky z matematiky, byt' by mělo jít jen o samotné základy této disciplíny. Dobře věděl, jak se různé hry s čísly dají snadno zneužít, a sám jim rozhodně nepodléhal. Jan Sokol byl matematikem, ale nefascinoval ho svět věčných geometrických jsoucen. Přiznám se, že mě to kdysi v jednom našem rozhovoru překvapilo, ale to jsem ho tehdy ještě málo znala. Později mi došlo, že na tom nic překvapivého nebylo. V centru zájmu Jana Sokola byl vždy člověk; matematický svět dokonalý, ale neživý, mu nijak neučaroval. Snad i proto studium matematiky nedokončil - převážil zájem o obory humanitní. V době svého dálkového studia na Matematicko-fyzikální fakultě se již pohyboval v prostředí bytových seminářơ, podílel se na připravovaném ekumenickém překladu Bible a překládal v tehdejších Čechách nedostupné a neznámé autory, jako byli Pierre Teilhard de Chardin, Maurice Blondel, Claude Tresmontant, Carl Friedrich von Weizsäcker, Karl Rahner nebo mistr Eckhart - to však zdaleka není výčet všech autorů, jejichž knihy Jan Sokol přeložil. Dohromady jde o obrovský kus práce, který zvládal samozřejmě vedle svého hlavního pracovního úvazku ve VÚMS.

Zásadní zlom do života Jana Sokola přinesl rok 1989, po kterém se, ostatně jako mnozí jeho přátelé, stal z disidenta politikem: v prvních svobodných volbách byl zvolen poslancem, byl předsedou poslaneckého klubu Občanského fóra a stal se místopředsedou Sněmovny národů Federálního shromáždění. Ačkoli v následujících volbách, tedy v roce 1992,již spolu s Občanským hnutím, za něž kandidoval, neuspěl, jeho stopa ve formování naší polistopadové politické kultury byla, domnívám se, výrazná. Do vysoké politiky se ještě dvakrát vrátil: nejprve v roce 1998 coby ministr školství v Tošovského vládě a poté jako protikandidát Václava Klause v prezidentských volbách v roce 2003. Na tom, že kdyby býval vyhrál, mohla se naše země ubírat nepoměrně lepší cestou, se dnes mnozí shodneme. Ale Jan Sokol se z politiky nevytratil, člověkem v pravém slova smyslu politickým nepřestal být, naopak: polis a správa věcí veřejných ho zajímaly, orientoval se $\mathrm{v}$ nich a promlouval k nim. Politiku chápal jako ,jednání s lidmi o veřejných věcech“ a v tomto smyslu ji neopustil nikdy: vždy byl ochoten do debaty přispět a jeho hlas nám bude chybět - zazníval totiž ve veřejném prostoru k aktuálním problémům, jasně a moudře, s nadhledem i trochou humoru.

Nutno připomenout, že jakkoli ho mnohé události posledních let, zejména na naší domácí politické scéně, zrovna netěšily, zůstával i v tomto ohledu optimistou. Nebyl z polistopadového vývoje zklamaný. Jednak proto, že, jak sám říkal, nečekal ráj na zemi a jeho očekávání byla v tomto ohledu střídmá a realistická, jednak proto, že byl člověkem bytostně pozitivním a nikdy si nenechal zastínit to dobré, co přece jen kolem sebe vždy máme, jen mnohdy nevidíme. A samozřejmě v tom hrála roli i jeho zkušenost a srovnání s režimem totalitním. Nepamatuji si, že by někdy naříkal - nadáváním na poměry čas neztrácel. Nebyl zvyklý jen čekat, co přijde; snažil se něco dělat a posouvat stav k lepšímu alespoň tam, kde na to stačil - at' už šlo o jeho nejbližší okolí, nebo o záležitosti veřejné. Debaty neodmítal a jezdil na různá setkání. Mnoha lidem se vybaví typická postava 
Jana Sokola s černým baretem kráčející zpravidla pěšky od nádraží... Diskutoval zejména o tématech, která mu ležela na srdci - snažil se argumentovat a vysvětlovat je lidem z různých sociálních, názorových či vzdělanostních skupin. Znepokojovala ho demagogie některých současných politiků založená na práci s lidským strachem. Měl ostatně s tím, jak to dopadá, když většina takovým řečem podlehne, bohatou osobní zkušenost. A tak např́klad trpělivě vysvětloval, že strach z muslimských migrantů v zemi, kde prakticky žádní nejsou, není vůbec na místě... Jeho mnohaletá přednášková činnost přesahující daleko akademickou půdu byla projevem jeho důvěry v sílu vzdělání a výchovy.

Proto také věnoval tolik svých sil vzdělávání a universitě. Směl na ní samozřejmě učit až po roce 1989, kdy mohl též sám oficiálně dostudovat humanitní obory. Šlo však spíše o stvrzení jeho erudice, kterou získal daleko dříve - právě v prostředí debat bytových seminářu a při překládání knih. Většinou v okruhu přátel, s nimiž ho seznámila jeho žena Františka, dcera Jana Patočky.

Sám Jan Sokol na dobu bytových seminářů a lidi, které na nich potkával, vzpomínal vždy jako na dobu a setkání, která pro něj byla jednoznačně formativní. Jako by se mu v tomto prostředí otevřel zcela nový svět. Vzhledem $\mathrm{k}$ jeho rodinnému zázemí se mi ten akcent zdál vždy poněkud zvláštní. Vždyt' pocházel z intelektuálské rodiny, tatínek byl architekt, maminka kunsthistorička a mezi jejich přátele patřili třeba Jaroslav Seifert či František Tichý, ale i již zmiňovaný Jan Patočka nebo Václav Černý. Pro Jana Sokola bylo ale setkání s Jiřím Němcem a okruhem lidí kolem něho a jeho ženy Dany opravdu klíčové. Šlo většinou o praktikující katolíky, kteří Janu Sokolovi ukázali ještě jinou podobu katolictví, než byla ta řekněme tradiční, $v$ níž byl vychováván a která mu coby patnáctiletému jaksi přestala stačit. Ukázali mu podobu víry, která není souborem katechismových pouček, ale cestou, cestou důvěry a spolehnutí se, po které kráčel do posledních dní. To bylo podstatné pro jeho opětné sblížení s katolickou církví, v jejímž prostředí se pohyboval a kterou považoval za svůj „domov“. Byl však bytostným ekumenikem a měl řadu přátel z jiných církví, především z evangelické. Jan Sokol byl nejen jednou z nejvýraznějších postav křest’anského disentu, ale aktivně činný byl v církvi i ve svobodných dobách, spolupracoval s Českou křest'anskou akademií a jedenáct let obohacoval svými kázáními bohoslužby břevnovské farnosti v bazilice sv. Markéty.

Diskuse $\mathrm{v}$ rámci bytových seminářů a překladatelská práce $\mathrm{s}$ nimi spojená byly pro Jana Sokola významné i z hlediska jeho profesního směřování po revoluci. Nemám ted’ na mysli jeho politické angažmá, které považoval podobně jako řada jeho spolusignatářůn-chartistů za přirozený krok, za službu, kterou má člověk nabídnout spoluobčanům, jejichž důvěře se těší. Myslím na jeho př́íklon k humanitním vědám, které si ho získaly a kterým se věnoval na universitě až do konce života.

Tak jako byl pro mne osobně Jan Sokol výraznou postavou politiky, stejně výrazně zapůsobil na nás, kteří jsme v době porevoluční studovali na universitě. Přesvědčivost našich tehdejších učitelů, kteří najednou mohli přednášet veřejně, měla bezesporu souvislost $\mathrm{s}$ atmosférou oněch bytových seminářù, kterými 
prošli či je i sami pořádali. Fascinace, kterou v nás posluchačích vzbuzovaly přednášky Ladislava Hejdánka, Erazima Koháka nebo právě Jana Sokola, spočívala $\mathrm{v}$ tom, že pro ně filosofie nebyla akademickým podnikem, ale živým dotazováním se, které zcela konkrétně formovalo jejich vlastní životní cesty. I díky tomu byl Jan Sokol tak oblíbeným učitelem - nepředkládal žádnou školskou filosofii, ale myšlenky, které - vezmeme-li je vážně - nutí k svému promítnutí do konkrétních životních postojů a kroků. Byla to živá filosofie v pravém slova smyslu. Jeho studenti vždy cítili, že nejde jen o nějaké penzum vědomostí, ale opravdové vzdělávání. Že v posledku nejde o diplom, kterým studium zakončí; věděli, že od Jana Sokola dostávají daleko víc. Pokračoval v tradici myslitelů, jako byli Emanuel Rádl, Tomáš Garrigue Masaryk a Václav Havel či Sokolův tchán Jan Patočka, tedy těch, kteří své poznání stvrzovali činy.

Mezi takové činy nepatří jen politická angažovanost Jana Sokola. Přesvědčení o významu výchovy a vzdělání ho - nejen na postu ministra školství - vedlo k zájmu o co nejlepší podobu a organizaci jeho institucionalizované podoby. Jak by mělo vypadat vysokoškolské studium, promýšleli společně se Zdeňkem Pincem ještě v době totality. Ve svobodné společnosti se pokusili - a to úspěšně - převést svoje představy do reality. Nejprve v podobě Institutu základů vzdělanosti, v roce 2000 pak založením Fakulty humanitních studií Univerzity Karlovy, jejímž byl Jan Sokol prvním děkanem. Do formy studia na naší fakultě, zejména jejího široce koncipovaného výrazně liberálního bakalářského programu, se propsalo přesvědčení Jana Sokola o potřebě humanitní vzdělanosti. Chtěl vychovávat lidi s širokým rozhledem, kteří nepropadnou žádnému „fachidiotství“, jak sám říkával. A nebyl to z jeho strany výraz přezíravosti k těm, kdo jsou dobrými odborníky ve svých disciplínách, jen varování před úzkou oborovostí, která může být omezující a jíž sám rozhodně nepodléhal.

Širre intelektuálního záběru Jana Sokola byla ohromná a nebývalá. V tomto smyslu bývá označován za myslitele „renesančního“ či „polyhistora“, což platí jen v jistém ohledu. Představa myslitele „renesančního“ totiž implikuje - alespoň v mém vnímání - tak trochu rozevlátost či zvídavost rozbíhající se různými směry. Jan Sokol byl však př̌ svém až neuvěřitelném rozhledu a přehledu zároveň osobností střídmou a soustředěnou. A to ve dvojím smyslu: jednak byl vždy při tom, co dělal. Byl dané chvíli opravdu přítomen. Ne že by neplánoval a nepřemýšlel dopředu, ne že by nevzpomínal a nereflektoval minulé - naopak, z minulosti se uměl poučit a dokázal to zúročit jako málokdo. Vždy se však soustředil na to, co právě dělal, a především na toho, s kým mluvil, a na to, co mu druhý říká. Dával tím najevo, že si jej váží, že je s ním v daný okamžik opravdu v dialogu, který je otevřený a z něhož může vzejít něco nového pro obě strany. A bylo jedno, zda proti němu seděl věhlasný profesor nebo student prvního ročníku. Zajímal se o názor druhého a nedával najevo intelektuální př̀vahu. Studenti to cítili a měli ho za to rádi.

Ona vnitřní soustředěnost snad způsobovala i jeho vyrovnanost a klid, který kolem sebe šírill. Přesto, že jsem mu na fakultě mohla být hodně let nablízku, nepamatuji si ho nikdy ve spěchu. Bylo mi vždy záhadou, jak je možné, že toho 
tolik stihne - psát, přednášet, číst, orientovat se v současném dění... Snad proto, že uměl vážit čas a rozlišovat mezi podstatným a nepodstatným - a s tím druhým čas opravdu neztrácel.

Jakási soustředěnost je cítit i z jeho textů, at' už je řadíme k filosofii, či antropologii, at' se věnují vědě, či náboženství, institucím a politice, či etice. Sám Jan Sokol takto neškatulkoval, resp. jeho texty samy se jednoznačnému zařazení vzpírají.

Často se uvádí, že měl nadání říkat složité věci jednoduchým a srozumitelným zpo̊sobem. To jistě ano. Nešlo ovšem jen o schopnost jasně se vyjádřit (a nepodlehnout př́ípadnému pokušení předvést se, oslnit čtenáře či posluchače svojí sečtělostí a znalostí - intelektuálním hrám nepodléhal). To, že uměl složité věci vyjádřit jednoduše a srozumitelně, bylo podloženo tím, že je nejprve dokázal poctivě promyslet. Až poté mohl vyslovit výměr na první pohled jednoduchý a přece silný, nap̌r. že pravda je to, na co se dá spolehnout, nebo určit svobodu jako prostor mezi „nemohu“ a „nesmím“. Promýšlel s jasným cílem porozumět, aby to k něčemu bylo. Totiž aby člověk věděl, jak jednat. Sám přiznával, že ho nezajímaly dějiny filosofie ani ontologie jaksi o sobě. Jakkoli byla jeho universitní kariéra strmá, nebyl typem akademického vědce či filosofa. Jeho myšlenkové zaměření formoval život, živý zájem o druhé a společnost. Ne že by se v dějinách filosofie neorientoval, naopak: jen málo lidí je tak sečtělých, jako byl on. Jakkoli mu to jeho znalosti umožňovaly, nestal se však „odborníkem na“ Platóna, Kanta či Nietzscheho. Filosofoval sám, a nesnažil se přitom vytvořit filosofický systém, ostatně k pokusům zachytit a pokrýt všechno byl poměrně skeptický (a měl pro ně i označení - ,,vesmír a okolí“). Přesto byl konsistentní. Jeho texty a přednášky vytvářejí organický celek myšlenek, které do sebe zapadají. Snad v nich lze tušit odpovědi na ony tři slavné Kantovy otázky: Co mohu vědět? Jak mám jednat? V co mohu doufat? Sám Sokol svůj prvotní zájem o filosofii vysvětloval opravdu potřebou ujasnit si, jak jednat ve vlastně zcela praktické situaci. A tímto nárokem bylo vedeno jeho filosofování i nadále - hlavní otázkou Jana Sokola vždy zůstávalo, jak má člověk žít.

Jedním z leitmotivů, které Jan Sokol sledoval, je pojetí života jako dluhu či dědictví. Daru, který jsme si ničím nezasloužili a máme se o něj starat. A to at' již máme na mysli život jednotlivce, nebo život vůbec. Pro chápání života, ale i pro myšlení Jana Sokola obecně měl klíčový význam francouzský filosof a theolog Pierre Teilhard de Chardin, k jehož knihám se dostal díky Jiřímu Němcovi již v šedesátých letech. Jakkoli v díle Jana Sokola nalézáme podněty od mnoha dalších autorů, setkání s Teilhardem bylo pro jeho další směřování opravdu zásadní. Otevřelo mu totiž zcela nový pohled na život a svět: pohled křest'anský, slučující evoluční teorii s biblickým chápáním světa jako Božího stvoření. Když Honza na ten šokující objev vzpomínal, naprosto jsem mu rozuměla a musela se vnitřně pousmát - mám za sebou totiž zkušenost téměř identickou. Ovšem s tím rozdílem, že já četla Teilharda v českém překladu - byla jsem tehdy na gymnáziu a jméno Jana Sokola, překladatele uváděného v tiráži, jsem ještě ani neznala a kdoví, zda to nebylo poprvé, kdy jsem je vůbec zaznamenala. 
Dnes jsem neskonale vděčná, že jsem ho mohla poznat osobně a být mu tolik let nablízku. Jakkoli byl výjimečný množstvím svých talentů a obdarování i tím, jak je dokázal zúročit, zůstával Jan Sokol neuvěřitelně skromný, a tak jsem tuto šîri odkrývala postupně. Spolu s tím stále zřetelněji vystupovala ona vnitřní jednota či integrita, úběžník patrný ze všeho, co dělal, jímž byla v posledku víra neokázalé a ryzí křest'anství. Chvíli mi trvalo, než jsem to rozpoznala. Ostatně jedním z prvních překladů Jana Sokola byl výběr z evangelií publikovaný pod názvem Poselství Ježíšovo, knižně vyšla i jeho nedělní kázání z břevnovského kláštera (Naděje na neděli). A tak se mi zdá až symbolické, že poslední promluvy, které pro svoji farnost ještě v lednu tohoto roku prripravil, byly na téma „vyznání víry“. Credem byl totiž celý život Jana Sokola.

Marie Pětová 